\title{
Insecticide Activity of Weeds to Pests of Stored Product and Crops
}

\author{
Juno F. Silva Diniz ${ }^{1}$, Paulo R. da Silva ${ }^{1}$, Marcelo R. dos Reis ${ }^{1}$, Ricardo T. Endo ${ }^{1}$, Rodrigo S. Ramos ${ }^{2}$, Flávio L. \\ Fernandes $^{1} \&$ Ítalo W. da Silva ${ }^{1}$ \\ ${ }^{1}$ Manejo Integrado de Pragas e de Plantas Daninhas, Universidade Federal de Viçosa - Campus de Rio Paranaíba, \\ Minas Gerais, Brazil \\ ${ }^{2}$ Entomologia, Universidade Federal de Viçosa, Viçosa, Minas Gerais, Brazil \\ Correspondence: Flávio Lemes Fernandes, Universidade Federal de Viçosa, Campus de Rio Paranaíba, MG 230, \\ KM 09, 38810-000, Rio Paranaíba, Minas Gerais, Brazil. Tel: 55-34-3855-9364. E-mail: flaviofernandes@ufv.br
}

Received: March 25, 2014 Accepted: May 14, 2014 Online Published: June 15, 2014

doi:10.5539/jas.v6n7p194 URL: http://dx.doi.org/10.5539/jas.v6n7p194

\begin{abstract}
Farmers from family farming faces serious problems of pest attack, both in their production on the field and in storage. The weed species with insecticidal action were identified through toxicity tests to insects. The species of plants tested were Ageratumm conyzoides, Euphorbia heterophylla, Sida rhombifolia and Sida spinosa and the insects were Leucoptera coffeella, Macrosiphum rosae, Atta sexdens rubropilosa, Solenopsis invicta and Sitophilus zeamais. The aim of this study was to identify weeds with insecticide activity against agricultural pests, extract the active compounds of weeds and perform bioassays with hexane and ethanol extracts of weeds on agricultural pests and stored grain. The plant material was subjected to extraction with ethanol and hexane. The mortality bioassays were conducted in a completely randomized design with four replications in triple factorial design ( $4 \times 5 \times 2)$. The data of mortality were subjected to analysis of variance and the differences among means were compared by Tukey's test $(\mathrm{p}<0.05)$. We detected significant differences between the mortality rates for the different species of plants, insect species and between the types of solvents and also in the interactions between insect species $\mathrm{x}$ types of solvents, plant species $\mathrm{x}$ types of solvents, plant species $\mathrm{x}$ insect species and between plant species $\mathrm{x}$ species of insects and types of solvents. In general, the hexane extracts of the plant species $A$. conyzoides and $S$. rhombifolia were the most toxic. The most susceptible insects species were $L$. coffeella, S. invicta and M. rosae.
\end{abstract}

Keywords: bioassays, extracts, insects, solvent

\section{Introduction}

Family farming is responsible for about $40 \%$ of Brazilian agricultural production and has a large capacity to generate foreign exchange earnings, employment and income, contributing to maintaining the quality of life of rural populations. Family farming uses a system of ecologically-based production which gathers techniques that aim to reduce dependence on foreign energy and environmental impact, obtaining better quality products, valuing the producer, their social bases, their work, their culture and their territory.

One of the main problems faced by farmers of family farming is the attack of pests, both in their production on the field and in storage. Thus, the producers use control practices, being the application of the most widely used organosynthetic insecticides. This method of control raises the cost of production due to the high value of these inputs and can result in ecotoxicological problems such as environmental pollution, poisoning of farmers and food contamination produced. A viable alternative to this situation is the use of botanical insecticides. These compounds have a low cost (and may even be produced by the farmers themselves), low environmental impact and are of low toxicity to humans and non-target organisms (Macías, Castellano, \& Molinillo, 2000).

The plants have a large diversity of compounds with insecticidal action, acaricidal, fungicidal and bactericidal, which have been used by botanical extracts as commercial products or as a source of molecules for the synthesis of pesticide by industries. Particularly the biodiversity of native plants is high in the Cerrado (Savannah) biome of Brazil, hence, the flora of this area has high potential of substances with insecticidal effects (Barbosa \& Fearnside, 2004).

Natural products from plants can be used the pattern for the synthesis of synthetic pesticides with desirable features such as greater efficiency, biodegradability and lower toxicity to non-target organisms. Among these 
substances may be mentioned polyphenols and phenolic compounds, quinones, flavonoids, tannins, coumarins, terpenoids, essential oils, alkaloids, lectins, polypeptides, among other compounds. Some plants with pesticidal activity have been studied. Plants of the families Meliaceae, Rutaceae, Asteraceae, Annonaceae, Labiatae and Canellaceae are considered the most promising (Jacobson, 1990).

Some plants such as Melliaceae (Azadirachta indica, Trichilia pallida and Melia azadarach), Asteraceae (Chrysanthemum cinerariaefolium and C. cineum), Fabaceae (Lonchocarpus spp., Derris spp.), Melanthiaceae (Schoenocaulon officinale), Salicaceae (Ryania speciosa), Solanaceae (Lycopersicon spp. and Nicotiana tabacum), Citrus spp., Cucurbitaceae (Piper spp.), Alliaceae (Allium sativum), Myrtaceae (Eucalyptus citriodora), and Euphorbiaceae (Manihot esculenta) have recognized toxic activity to insect (Moura et al., 2005).

In relation to weeds, purple nutsedge (Cyperus rotundus) is the main weed specie in cultivated soils in tropical regions. According to Borella and Pastorini (2009), and Arantes et al. (2005) C. rotundus is rich in alkaloids, anthraquinones, coumarins, steroids and triterpenes, flavonoids, saponins, tannins and resins capable of presenting insecticide effect and/or repellents to arthropods. The billy goat-weed Ageratum conyzoides L. (Asteraceae) is a plant known in Brazil and in other countries of America. The extract of this plant has properties such as phytotherapics, analgesic, healing, allelopathic, antimicrobial and insecticides (Magalhães et al., 1998; Bouda, Tapondjou, Fontem, \& Gumedzoe, 2001; Moura et al., 2005). Several classes of compounds have been described as mono and sesquiterpenes, triterpenes, flavonoids, sterols and alkaloids essential oil, consisting of precocenos (I and II) variants 30-93\% (Ming, 1999). Other species like Sida spinosa and S. rhombifolia are rich in alkaloids, which are extremely toxic to arthropods. Euphorbia heterophylla has been considered toxic to insects having in their chemical constitution undiscovered insecticide molecules (Guerra, 1985).

Although weeds are seen as harmful to human activity, these plants can contain important insecticide molecules for the control of pests. Thus, the identification of weeds with insecticidal activity through testing the toxicity to insects should be investigated. This study aimed to identify weeds of the Cerrado with insecticide activity against agricultural pests and extract active compounds of weeds and performs bioassays with hexane and ethanol extracts of weeds on agricultural pests and stored grain.

\section{Materials and Methods}

The study was conducted in the laboratory of Chemistry and Entomology, at the Universidade Federal de Viçosa - Campus Rio Paranaíba, State of Minas Gerais, Brazil, from August 2011 to June 2012. The weed species from the Cerrado were tested (Table 1). These plant species were selected based on data from literature, popular knowledge by chemotaxonomy, whereas plants of the same family or immediate families may have similar active compounds (Guerra, 1985; Moreira et al., 1995). The insect species which were studied are key pests of agricultural crops and storage (Pedigo \& Rice, 2006). The pest insects used were obtained from laboratory rearing or crops in the field.

Table 1. Common name, family, species and phenological stage of weed species.

\begin{tabular}{llll}
\hline Common Name & Family & Species & Phenological Stage \\
\hline Prickly sida & Malvaceae & Sida spinosa & Reproductive \\
Billy goat weed & Asteraceae & Ageratum conyzoides & Reproductive \\
Wild poinsettia & Euphorbiaceae & Euphorbia heterophylla & Vegetative \\
Arrow leaf sida & Malvaceae & Sida rhombifolia & Reproductive \\
\hline
\end{tabular}

The agricultural pests were: Macrosiphum rosae (L.) (Hemiptera: Aphididae) (key pest of rose plants). Leucoptera coffeella (Guérin-Mèneville \& Perrottet) (Lepidoptera: Lyonetiidae) (key pest of coffee plant). The lemon leaf-cutting ant, Atta sexdens rubropilosa (Forel) (Hymenoptera: Formicidae) and the fire ant Solenopsis invicta (Hymenoptera: Formicidae) (key pest of several crops) (Table 2). We use only for stored grain the maize weevil Sitophilus zeamais (Motsch.) (Coleoptera: Curculionidae) (Key pest of corn) (Tables 1 and 2).

To obtain extracts of the plant material was weighed fresh and subjected to extraction with hexane and ethanol in 1000-2000 mL glass Erlenmeyer flask. The hexane extraction aims at extracting non-polar substances, on the other hand ethanolic extraction aims at extracting polar substances. The amount of solvent used was a $1 \mathrm{~L}$, sufficient to fully immerse the plant material. After 48 hours, hexane and ethanol solution were removed under filtration. The extracts were concentrated on a rotary evaporator at low pressure and low temperature $\left(<50{ }^{\circ} \mathrm{C}\right)$. 
The resulting extracts were stored over the refrigerating in ultra-low temperature until the realization of the bioassays (Moreira, Picanço, Barbosa, Guedes, \& Silva, 2004).

Table 2. Order, family, species and stage of species of agricultural insect pests and stored grain

\begin{tabular}{llll}
\hline Order & Family & Species & Stage \\
\hline Coleoptera & Curculionidae & Sitophilus zeamais & Adult \\
Hemiptera & Aphididae & Macrosiphum rosae & Nymph \\
Hymenoptera & Formicidae & Atta sexdens rubopilosa & Adult \\
Hymenoptera & Formicidae & Solenopsis invicta & Adult \\
Lepidoptera & Lyonetiidae & Leucoptera coffeella & Caterpillar \\
\hline
\end{tabular}

\subsection{Bioassays of Mortality}

The experimental design was completely randomized with four replications in triple factorial $(4 \times 5 \times 2)$, four species of plants $\mathrm{x}$ five species of insects $\mathrm{x}$ two solvents of different polarity. Each plot consisted of a Petri dish ( $9 \mathrm{~cm}$ diameter by $2 \mathrm{~cm}$ height) containing insects.

The hexane extracts were diluted in acetone. It was distributed $0.5 \mathrm{~mL}$ of extract into filter paper of $9 \mathrm{~cm}$ diameter which was placed in a glass Petri dish. The control was treated only with $0.5 \mathrm{~mL}$ of the respective solvents. After evaporation of the solvent, 10 insects were added for each experimental unit. After 48 hours of exposure we evaluated the number of live and dead individuals (Moreira et al., 2004). In all assessments the insects were considered dead when they showed no mobility. Mortality data of insects in each botanical extract were subjected to analysis of variance and means were compared by Tukey $\mathrm{p}<0.05$.

\section{Results and Discussion}

Many studies have worked on the extraction and the insecticidal properties of plants (Gakuru \& Foua-Bi, 1996; Kimura, Mori, Susuki, \& Kobayashi, 1981; Meehan, 1980). We work report the insecticide activity in weeds, and we detected significant differences between the mortality depending on the plant species $\left(\mathrm{F}_{3,120}=10.16, \mathrm{p}\right.$ $<0.0001)$, insect species $\left(\mathrm{F}_{4,120}=31.30, \mathrm{p}<0.0001\right)$ and between types of solvents $\left(\mathrm{F}_{1,120}=89.73, \mathrm{p}<0.0001\right)$. Significant differences were also detected in the interactions between insect species $\mathrm{x}$ types of solvents $\left(\mathrm{F}_{4,120}=29.25, \mathrm{p}<0.0001\right)$, plant species $\mathrm{x}$ types of solvents $\left(\mathrm{F}_{3,120}=22.65, \mathrm{p}<0.0001\right)$, plant species $\mathrm{x}$ insect species $\left(\mathrm{F}_{12,120}=4.91, \mathrm{p}<0.0001\right)$ and between plant species $\mathrm{x}$ insect species and types of solvents $\left(\mathrm{F}_{12,120}=4.35\right.$; $\mathrm{p}<0.0001$ ). Thus, the extracts showed variable toxicity depending on the plant species and insect species for each type of solvent.

It was found that the ethanolic extract of $S$. spinosa showed significantly higher mortality only for lemon leaf-cutting ant, $A$. sexdens rubropilosa $(87.50 \%)$. Already, hexane extracts, the most susceptible species were $L$. coffeella, S. invicta (both $100 \%$ ) followed by M. rosae (80\%) (Table 3). The A. conyzoides was toxic to L. coffeella, S. invicta and M. rosae. The $S$. rhombifolia was toxic to $S$. invicta and L. coffeella, with mortality rates above $80 \%$ as required by the ministry of agriculture Agency.

Table 3. Mean mortality (\%) of species of insect pests according to the ethanol extracts obtained from weeds

\begin{tabular}{llllll}
\hline \multirow{2}{*}{ Plant species } & \multicolumn{5}{c}{ Insect species $^{1}$} \\
\cline { 2 - 6 } & Leucoptera coffeella & Sitophilus zeamais & Macrosiphum rosae & Atta sexdens rubropilosa & Solenopsis invicta \\
\hline Euphorbia heterophylla & $22.50 \mathrm{aA}$ & $5.00 \mathrm{aA}$ & $40.00 \mathrm{aA}$ & $47.50 \mathrm{aA}$ & $12.50 \mathrm{aA}$ \\
Ageratum conyzoides & $25.00 \mathrm{aA}$ & $7.50 \mathrm{aA}$ & $30.00 \mathrm{aA}$ & $30.00 \mathrm{aA}$ & $5.00 \mathrm{aA}$ \\
Sida rhombifolia & $5.00 \mathrm{aA}$ & $2.50 \mathrm{aA}$ & $17.50 \mathrm{aA}$ & $40.00 \mathrm{aA}$ & $2.50 \mathrm{aA}$ \\
Sida spinosa & $12.50 \mathrm{aB}$ & $5.00 \mathrm{aB}$ & $5.00 \mathrm{aB}$ & $87.50 \mathrm{aA}$ & $2.50 \mathrm{aB}$ \\
\hline
\end{tabular}

${ }^{1}$ Means followed by the same uppercase letter on the line and lowercase in column do not differ by Tukey test at $\mathrm{p}<0.05$. 
The hexane solvent showed higher mortality of the insect species than the ethanol solvent. The S. invicta, M. rosae and L. coffeella were the insects more susceptible to hexane solvent (Tabels 4 and 5). The plant extract of $E$. heterophylla caused a higher mortality of insect species. The hexane extract caused (60\%) mortality to $M$. rosae, followed by the ethanol extract to the $A$. sexdens rubropilosa $(47.5 \%)$. The hexane extract of the plant species A. conyzoide, compared to the same ethanol extract, caused greater mortality to L. coffeella $(100 \%), S$. invicta $(97.5 \%)$ and M. rosae (80\%). The plant species $S$. rhombifolia showed higher mortality with the hexane extract insect species S. invicta $(100 \%)$ and L. coffeella $(97.5 \%)$ compared to the ethanol extract. Regarding to plant extract of $S$. spinosa we had the highest mortality for ethanolic extract to the A. sexdens rubropilosa (87.5\%) followed by a hexane extract to the S. invicta (60\%), and M. rosae (47.5\%) (Table 6). Similar results were reported by Moreira et al. (2007), testing eight plants, verify that only the hexane extract of A. conyzoides showed insecticide activity to $R$. dominica, at 4 and 24 hours after the exposure. The higher toxicity of the hexane extracts to insects may be due to polarity of this solvent, since nonpolar compounds have a higher affinity for the insect cuticle and plant extracts have a high toxicity to insects via the cuticle. The azadirachtin (apolar compound), for example, causes changes in tissue differentiation (for example, the ommatidia and marginal discs wings) causing melanization of the cuticle and in mitosis by interfering similarly colchicine (Schlüter, 1985; Malczewska et al., 1988).

Table 4. Mean mortality (\%) of species of insect pests according to the hexane extracts obtained from weeds

\begin{tabular}{llllll}
\hline \multirow{2}{*}{ Plant species } & \multicolumn{5}{c}{ Insect species $^{1}$} \\
\cline { 2 - 5 } & Leucoptera coffeella & Sitophilus zeamais & Macrosiphum rosae & Atta sexdens rubropilosa & Solenopsis invicta \\
\hline Euphorbia heterophylla & $17.50 \mathrm{bBC}$ & $0.00 \mathrm{aC}$ & $60.00 \mathrm{aA}$ & $30.00 \mathrm{aB}$ & $20.00 \mathrm{cBC}$ \\
Ageratum conyzoides & $100.00 \mathrm{aA}$ & $2.50 \mathrm{aC}$ & $80.00 \mathrm{aAB}$ & $47.50 \mathrm{aB}$ & $97.50 \mathrm{aA}$ \\
Sida rhombifolia & $97.50 \mathrm{aA}$ & $0.00 \mathrm{aC}$ & $67.50 \mathrm{aB}$ & $50.00 \mathrm{aB}$ & $100.00 \mathrm{aA}$ \\
Sida spinosa & $12.50 \mathrm{bBC}$ & $5.00 \mathrm{aC}$ & $47.50 \mathrm{aAB}$ & $22.50 \mathrm{aBC}$ & $60.00 \mathrm{bA}$ \\
\hline
\end{tabular}

${ }^{1}$ Means followed by the same uppercase letter on the line and lowercase in column do not differ by Tukey test at $\mathrm{p}<0.05$.

Table 5. Effect of the solvent used in the extraction of compounds from the plant species (Ageratum conyzoides, Euphorbia heterophylla, Sida rhombifolia and Sida spinosa) in the mean mortality (\%) of species of insect pests

\begin{tabular}{llllll}
\hline & \multicolumn{5}{c}{ Insect species $^{1}$} \\
\cline { 2 - 6 } Solvents & Leucoptera coffeella & Sitophilus zeamais & Macrosiphum rosae & Atta exden rubropilosa & Solenopsis invicta \\
\hline Ethanol & $16.25 \mathrm{bB}$ & $5.00 \mathrm{aB}$ & $23.12 \mathrm{bB}$ & $51.25 \mathrm{aA}$ & $5.62 \mathrm{bB}$ \\
Hexane & $56.87 \mathrm{aAB}$ & $1.87 \mathrm{Ac}$ & $63.75 \mathrm{aAB}$ & $37.50 \mathrm{aB}$ & $69.37 \mathrm{aA}$ \\
\hline
\end{tabular}

${ }^{1}$ Means followed by the same uppercase letter on the line and lowercase in column do not differ by Tukey test at $\mathrm{p}<0.05$.

Table 6. Effect of solvents and plant extracts on insect mortality

\begin{tabular}{lllllllll}
\hline \multicolumn{7}{c}{ Plant species / Solvents } \\
\hline Insect species & \multicolumn{1}{c}{ Euphorbia heterophylla } & Ageratum conyzoides & Sida rhombifolia & Sida spinosa \\
\cline { 2 - 10 } & Ethanol & Hexane & Ethanol & Hexane & Ethanol & Hexane & Ethanol & Hexane \\
\hline Leucoptera coffeella & $22.50 \mathrm{a}$ & $17.50 \mathrm{a}$ & $25.00 \mathrm{~b}$ & $100.00 \mathrm{a}$ & $5.00 \mathrm{~b}$ & $97.50 \mathrm{a}$ & $12.50 \mathrm{a}$ & $12.50 \mathrm{a}$ \\
Sitophilus zeamais & $5.00 \mathrm{a}$ & $17.50 \mathrm{a}$ & $7.50 \mathrm{a}$ & $2.50 \mathrm{a}$ & $2.50 \mathrm{a}$ & $0.00 \mathrm{a}$ & $5.00 \mathrm{a}$ & $5.00 \mathrm{a}$ \\
Macrosiphum rosae & $40.00 \mathrm{~b}$ & $60.00 \mathrm{a}$ & $30.00 \mathrm{~b}$ & $80.00 \mathrm{a}$ & $17.50 \mathrm{~b}$ & $67.50 \mathrm{a}$ & $5.00 \mathrm{~b}$ & $47.50 \mathrm{a}$ \\
Atta sexdens rubropilosa & $47.50 \mathrm{a}$ & $30.00 \mathrm{a}$ & $30.00 \mathrm{a}$ & $47.50 \mathrm{a}$ & $40.00 \mathrm{a}$ & $50.00 \mathrm{a}$ & $87.50 \mathrm{a}$ & $22.50 \mathrm{~b}$ \\
Solenopsis invicta & $12.50 \mathrm{a}$ & $20.00 \mathrm{a}$ & $5.00 \mathrm{~b}$ & $97.50 \mathrm{a}$ & $2.50 \mathrm{~b}$ & $100.00 \mathrm{a}$ & $2.50 \mathrm{~b}$ & $60.00 \mathrm{a}$
\end{tabular}

${ }^{1}$ Means followed by the same lowercase in the row for ethanol and hexane solvents in each plant species do not differ by Tukey test at $\mathrm{p}<0.05$. 
The toxicity of plant species to L. coffeella, S. invicta and M. rosae is related to the collection time, plant age, soil type, nutrition and climatic conditions of the biome that these plants were collected. The Billygoat-weed $A$. conyzoides has caused mortality in insects of the orders Lepidoptera, Hymenoptera, Coleoptera, Hemiptera and Diptera, which include the species studied in this work (Moreira et al., 2007; Araújo et al., 2008; Soares et al., 2011). The S. rhombifolia have also shown toxicity to several insect orders (Guerra, 1985; Laca-Buendia \& Brandão, 1988). We conclude that hexane extracts of the plant species A. conyzoide and S. rhombifolia were the most toxic. The species most susceptible insects were L. coffeella, S. invicta and M. rosae.

The use of some botanical extracts containing phytochemicals in the control of pest is promising. However, more studies, both laboratory and plantations, are needed to make more definitive conclusions regarding safety and efficacy.

\section{Acknowledgements}

The funding and fellowships provided by the following Brazilian agencies are acknowledged: CAPES Foundation (Ministry of Education), National Council of Scientific and Technological Development (CNPq) and Minas Gerais State Foundation for Research Aid (FAPEMIG).

\section{References}

Arantes, M. C. B., Oliveira, L. M. G., Freitas, M. R. F., Silva, L. N. M., Nogueira, J. C. M., Paula, J. R., \& Bara, M. T. F. (2005). Estudo farmacognóstico do Cyperus rotundus L. Revista Eletrônica de Farmácia, 2, 17-20.

Araújo, M. S., Lucia, T. M. C. D., Moreira, M. D., \& Picanço, M. C. (2008). Toxicidade de extratos hexânicos de plantas às operárias de Atta laevigata e Acromyrmex subterraneus subterraneus (Formicidae: Attini). Revista Brasileira Agrociência, 14, 106-114.

Barbosa, R. I., \& Fearnside, P. M. (2004). Wood density of trees in open savannas of the Brazilian Amazon. Forest Ecology and Management, 199, 115-123. http://dx.doi.org/10.1016/j.foreco.2004.05.035

Borella, J., \& Pastorini, L. H. (2009). Influência alelopática de Phytolacca dioica L. na germinação e crescimento inicial de tomate e picão-preto. Revista Biotemas, 22, 67-75.

Bouda, H., Tapondjou, A., Fontem, D. A., \& Gumedzoe, M. Y. (2001). Effect of essential oils from leaves of Ageratum conyzoides, Lantana camara and Chromolaena odorata on the mortality of Sitophilus zeamais (Coleoptera: Curculionidae). Journal Stored Product Research, 37, 103-109. http://dx.doi.org/10.1016/ S0022-474X(00)00011-4.

Gakuru, S., \& Foua-Bi, K. (1996). Effet d'extraits de plantes sur la bruche du niébé (Callosobruchus maculatus Fab.) et le charançon du riz (Sitophilus oryzae L.). Cahiers Agriculture, 5, 39-42.

Guerra, M. S. (1985). Receituário caseiro: alternativas para o controle de pragas e doenças de plantas cultivadas e seus produtos. Brasília, BR: Embrater.

Jacobson, M. (1990). Botanical pesticides: past, present and future. In J. T. Arnason, B. J. R. Philogène, \& P. Morand (Eds.), Insecticide of plant origin. Washington, DC: American Chemical Society.

Kimura, T., Mori, M., Susuki, A., \& Kobayashi, A. (1981). Isolation and identification of two nematicidal substances from roots of Erigeron philadephicus L. and nematicidal activities of their related compounds. Agriculture and Biological Chemistry, 45, 2915-2917. http://dx.doi.org/10.1271/bbb1961.45.2915

Lac-Buendia, J. P., \& Brandão, M. (1988). Usos pouco conhecidos de plantas daninhas como companheiras, repelentes, inseticidas, iscas, moluscocidas e nematicidas. Informe Agropecuário, 13, 30-33.

Macías, F. A., Castellano, D. \& Molinillo, J. M. G. (2000). Search for a standard phytotoxic bioassay for allelochemicals. Selection of standard target species. Journal of Agriculture and Food Chemistry, 48, 2512-2521. http://dx.doi.org/10.1021/jf9903051

Magalhães, J. F. G., Viana, C. F. G., Aragão Junior, A. G. M., Moraes, V., Ribeiro, R. A., \& Vale, M. R. (1998). Analgesic and antiinflammatory activities of Ageratum conyzoides in rats. Phytotherapy Research, 11, 183-188. http://dx.doi.org/10.1002/(SICI)1099-1573(199705)11:3<183::AID-PTR63>3.0.CO;2-8

Malczewska, M., Gelman, D. B., \& Cymborowski, B. (1988). Effects of azadirachtin on development, juvenile hormone and ecdysteroid titres in chilled Galleria mellonela larvae. Journal of Insect Physiology, 34, 725-732. http://dx.doi.org/10.1016/0022-1910(88)90084-4

Ming, L. C. (1999). Ageratum conyzoides: A tropical source of medicinal and agricultural products. In J. Janick (Ed.), Perspectives on new crops and new uses. Alexandria: ASHS. 
Moreira, M. D., Picanço, M. C., Barbosa, L. C. D. A., Guedes, R. N. C., \& Silva E. M. D. (2004). Toxicity of leaf extracts of Ageratum conyzoides to Lepidoptera pests of horticultural crops. Biological Agriculture and Horticulture, 22, 1-10. http://dx.doi.org/10.1080/01448765.2004.9755288

Moreira, M. D., Picanço, M. C., Silva, E. M., Moreno, S. C., \& Martins, J. C. (2005). Uso de inseticidas botânicos no controle de pragas. In M. Venzon, T. J. Paula Júnior, \& A. Pallini Filho (Eds.), Controle alternativo de pragas e doenças. Belo Horizonte, MG, Epamig.

Moreira, R. A., Cordeiro, E. F., Cavada, B. S., Nunes, E. P., Fernandes, A. G., \& Oliveira, J. T. A. (1995). Lactins and the chemotaxonomy of the sub-tribe Diocleinae (Leguminosae-Phaseolaeae). Revista Brasileira de Fisiologia Vegetal, 7, 7-14.

Moura, A. C. A., Silva, E. L. F., Fraga, M. C. A., Wanderley, A. G., Afiatpour, P., \& Maia, M. B. S. (2005). Anti-inflammatory and chronic toxicity study of the leaves of Ageratum conyzoides L. in rats. Phytomedicine, 12, 138-142. http://dx.doi.org/10.1016/j.phymed.2003.12.003

Pedigo, L. P., \& Rice, M. E. (2006). Entomology and pest management. New Jersey, NJ: Prentice-Hall.

Schlüter, U. (1985). Occurrence of weight gain reduction and inhibition of metamorphosis and storage protein formation in last instars of the beetle, Epilachna varivestis, after injection of azadirachtin. Entomologia Experimentalis et Applicata, 39, 191-195. http://dx.doi.org/10.1111/j.1570-7458.1985.tb03562.x

Soares, C. S. A., Silva, M., Costa, M. B., \& Bezerra, C. E. S. (2011). Ação inseticida de óleos essenciais sobre a lagarta desfolhadora Thusrinteina arnobia (Stoll) (Lepidoptera: Geometridae). Revista Verde de Agroecologia e Desenvolvimento Sustentável, 6, 154-157.

\section{Copyrights}

Copyright for this article is retained by the author(s), with first publication rights granted to the journal.

This is an open-access article distributed under the terms and conditions of the Creative Commons Attribution license (http://creativecommons.org/licenses/by/3.0/). 